\title{
Pemberdayaan Masyarakat melalui Pemanfaatan Limbah Besi dalam pembuatan Produk “CIRCLE HANGER" sebagai Peningkatan Kesejahteraan Masyarakat dan Industri Kreatif yang Berdaya Saing
}

\author{
Lolyka Dewi Indrasari ${ }^{*}$, Silvi Rushanti Widodo ${ }^{2}$, Afiff Yudha Tripariyanto 3 , Ana Komari ${ }^{4}$, Sri \\ Rahayuningsih ${ }^{5}$, Imam Safi'i ${ }^{6}$, Heribertus Budi Santoso ${ }^{7}$, Titin Widya Risni ${ }^{8}$, Johan Alfian Pradana ${ }^{9}$ dan \\ Venus Khatta Salsabillah ${ }^{10}$ \\ 1,2,3dst Teknik Industri Fakultas Teknik, Universitas Kadiri, Jl. Selomangleng No 1 Pojok Kecamatan Mojoroto, Kota \\ Kediri, Jawa Timur, 64115, Indonesia \\ * Penulis Korespondensi: E-mail: $\underline{\text { lolyka@unik-kediri.ac.id }}$
}

\begin{abstract}
This community service has a purpose to know how the prosperity of the society in Dusun Combong, Kec. Gampengrejo, Kab. Kediri to execute the economic with utilization of iron waste for make the circle hanger that has a selling value and power value around the environment until Central Java area. To make the development for selling and quality development product, this community service has a goal, because without society who have a job, a product can not sell eventhough have a predict condition, so with this iron waste, hope can increase the significancy economic of society. Information that we find can give the positive impact to the owner and society. Circle hanger has market in each town who do the order before., and after this community service, society can produce a product fastly and can do evalution for increase the performance and do the competitiveness processes globally.
\end{abstract}

Keywords: Service, Circle Hanger, Waste.

\begin{abstract}
Abstrak
Pengabdian masyarakat yang dilakukan ini memiliki tujuan yaitu untuk mengetahui seberapa tinggi tingkat kesejahteraan masyarakat dusun Combong, Kec. Gampengrejo. Kab. Kediri dalam menjalankan roda perekonomian terhadap adanya pemanfaatan limbah besi kawat yang dijadikan untuk pembuatan produk Circle Hanger yang sudah memiliki nilai jual dan daya jual dilingkungan sekitar bahkan sampai area Jawa Tengah. Dalam melakukan pengembangan penjualan dan pengembangan kualitas produk, arah dari pengabdian yaitu menuju arah tingkat pemberdayaan masyarakatnya, karena tanpa adanya masyarakat yang diberdayakan, suatu produk tidak akan terjual meskipun dengan kondisi yang sesuai harapan, maka dengan adanya produk dari limbah besi, diharapkan mampu meningkatkan kesejahteraan masyarakat secara signifikan. Dalam penggalian informasi akan memberi dampak positif pada pemilik usaha dan pelaku yang bersangkutan. Circle Hanger yang dipasarkan sudah memiliki pelanggan masing- masing pada tiap kota yang dilakukan permintaan pembelian, serta setelah pemberdayaan masayarakat, maka secara tidak langsung masyarakat yang ikut terlibat juga memiliki kemampuan dalam hal membuat produksi produk menjadi lebih cepat dan melakukan evaluasi untuk meningkatkan kinerja dan melakukan proses- proses daya saing produk secara global.
\end{abstract}

Kata kunci: Pengabdian, Circle Hanger, Limbah.

\section{PENDAHULUAN}

Dalam melakukan sebuah pemanfaatan bahan limbah tergantung dengan untuk apa limbah tersebut agar dapat digunakan bagi khalayak umum ataupun pengguna yang 
bersangkutan. Pemanfaatan limbah selain untuk menambah inovasi produk, juga bermanfaat bagi lingkungan yaitu dalam lingkungan akan berkurang limbah yang tidak bisa diuraikan oleh lingkungan tersebut. Dari segi peluang, limbah dapat dimanfaatkan untuk menambah nilai mata uang bagi pengolahnyanya. Sebuah pembuatan produk memang pada dasarnya menggunakan bahan baku yang berasal dari perusahaan, tapi jika penggunaan bahan baku yang berasal dari limbah dapat dimanfaatkan menjadi lebih baik akan memberi dampak positif serta menambah keunikan terhadap produk tersebut. Dalam pemanfaatan limbah tersebut, maka juga harus diketahui tentang kualitas produk yang akan dikembangkan, karena hal tersebut menyangkut daya saing ketika produk sudah diproduksi dan masuk pasar serta dapat memberi kepuasan kepada pelanggan karena sesuai dengan apa yang diharapkan. Dalam lingkungan, pemanfaatan limbah dapat dikategorikan dalam lingkup industri kreatif, yang mana dalam industri kreatif tersebut merupakan aktivitas yang merupakan tuntutan agar timbul inovasi yang besar sehingga kreativitas - kreativitas yang belum muncul akan muncul seiring dengan berkembangnya informasi yang sudah dapat diakses dari sumber manapun dan terpercaya. Sebuah industri kreatif merupakan sumber masukan yang berupa ilmu-ilmu pengetahuan dan teknologi untuk mendorong perekonomian yang baik dan menciptakan iklim kreatif untuk tujuan pengembangan tersebut menurut Wiko (2010:22) (dalam Satria, n.d.).

Pengembangan industri kreatif tidak harus dengan mengandalkan bahan baku yang didapat dari pasar dalam kondisi yang bagus dan berkualitas, jika ada barang - barang yang sudah tidak layak pakai serta memiliki nilai jual ketika sudah melalui proses daur ulang, maka bahan- bahan tersebut dapat dijadikan produk industri kreatif. Pada pemanfaatannya, bahan bahan yang akan didaur ulang akan mengalami proses sedikt lebih lama dibandingkan dengan bahan- bahan yang sudah didapat dari pasar. Karena dalam bahan- bahan yang diperoleh dari limbah perlu diperhitungakan kualiatasnya apakah bagus ketika sudah memasuki tahap pengolahan atau merugikan ketika sudah dilakukan pengolahan. Maka, penentuan kualitas produk dari bahan daur ulang memang harus memiliki tingkat kepuasan yang didapat hanya dari individu tertentu maupun semua pelanggan yang pernah menggunakan produk tersebut. Kepuasan yang didapat pelanggan secara penuh yaitu sudah sesuai harapan atas produk yang sudah dihasilkan oleh produsen menurut Feigenbaum (1986:7) dalam Wulandari, Eripudia, \& Arifannisa, 2018). Pengertian mutu dalam aspek yang merupakan cara tangkap yang dapat diprediksi dari banyaknya keberagaman produk pada pasar dan memiliki sifat ketergantungan yang megacu pada biaya yang ditimbulkan ketika sudah dibeli karena biaya yang didapat dibawah harga pasar serta daya dalam penggunaannya sesuai harapan (Juran \& Deming dalam (Wulandari et al., 2018). Dengan adanya industri kreatif pemanfaatan bahan limbah untuk menaikkan nilai mutu dapat digunakan dalam langkah alternatif mengatasi kesenjangan sosial pada lingkungan yang bersangkutan. Kesejahteraan dalam artian disini yaitu dalam lingkup pemberdayaan masyarakat yang akan melakukan pemanfaatan barang limbah agar dijadikan suatu produk yang memiliki nilai guna bagi pengguna serta mampu dikonsumsi dalam pasar yang luas. Kegunaan kesejahteraan yaitu sebagai tolak ukur seberapa tinggi aktivitas - aktivitas yang dilakukan untuk mencapai proses - proses yang berkualitas yang mengarah pada pemberian fasilitas yang memadai dalam proses meningkatkan kesejahteraan, melakukan pembanguan berkaitan dengan moral, karakter serta perhatian pemerintah dalam melakukan usaha untuk peningkatan kesejahteraan (Miradj \& Sumarno, 2017). Kesejahteraan yang diungkapkan disini bukan terkait dengan keterbelakangan, keterlantaran, buta huruf dan pengangguran tapi disini lebih memiliki artian bahwa kesejahteraan harus dilakukan setiap individu dengan kesadaran diri terhadap apa yang ada potensi pada lingkunagn tempat tinggal. Sumber daya manusia memang dapat diartikan mayoritas kelompok menyebutnya 
dikarenakan faktor - faktor yang bernilai negatif, tapi pengaruh paling besar dalam sumber daya manusia yaitu terletak pada bagaimana seorang individu mampu dalam menciptakan ide, agar dapat diimplemtasikan guna memenuhi kebutuhan diera saat ini dan memiliki dampak positif bagi lingkungan, diri sendiri dan orang lain. Penyampaian informasi dan cara komunikasi seseorang akan berpengaruh dengan sifat yang akan dilakukannya, jika pemberian informasi dilakukan secara benar, memiliki motivasi tinggi dan dapat menggerakkan atau memberi efek positif maka akan menjadikan seorang individu atau kelompok dapat memahami potensi yang ada dan dapat dikembangkan untuk keperluan agar dapat memberi efek positif bagi pengguna maupun target.

Pada industri kreatif memiliki keunggulan pada kreatif dalam menciptakan desaindesain yang bisa menjadi daya tarik paa produk yang akan dihasilkan kemudian sangat berkaitan dengan kondisi sumber daya manusia yang memiliki sifat ingin membuat perubahan baru dan memberi dampak posistif terhadap kesejahteraan individu maupun kelompok yang bersangkutan menurut Howkin (2001) dalam (Rohman, 2019). Dalam hal ini, perubahan yang dilakukan dapat memberi kepuasan jika dalam lingkup produk yang digunakan oleh pengguna, dalam penggunaan produk, akan timbul penilaian setelah terjadi penggunaan, karena akan menimbulkan nilai ekspetasi dan nilai performa persepsi. Karena jika produk yang dihasilkan memiliki nilai persepsi tinggi yang melebihi nilai ekspetasi, maka kepuasan pengguna terhadap produk tersebut sangat tinggi. Dengan adanya loyalitas pelanggan, maka pelanggan akan kembali lagi untuk menggunakan produk tersebut dan produsen tidak perlu mencari lagi pelanggan karena sudah memiliki pelanggan lama.

Dusun Combong merupakan desa yang berada pada wilayah desa Wanengpaten sebelah timur dusun Babatan, Desa Ngebrak, dalam desa tersebut terdapat industri kreatif yang memanfaatkan limbah besi dari sisa - sisa produksi pabrik kertas Surya Zig-Zag digunakan untuk pembuatan produk hanger yang berbentuk bulat, yang dinamakan circle hanger. Jumlah yang memproduksi di Dusun Combong adalah 10 rumah tangga. Mulai terbentunya usaha ini pada tahun 2003 dan turun temurun sampai ke anak cucunya sampai sekarang. Yang lebih unik disini dari produksi hanger baju pada umumnya sekarang sudah mendapatkan inovasi baru yakni dengan membuat Circle Hanger. Bila secara umum oraang memproduksi produk barang memerlukan bahan baku yang baru, Circle hanger ini menggunakan bahan baku dari limbah industri dari PT. Zig - Zag yang berada tidak jauh dari lokasi desa tersebut. Limbah industri yang dimaksud adalah dari bongkaran pallet kertas yang dimana ada kawat yang mengikatnya, kawat inilah yang kemudian dibeli oleh masyarakat Desa Wenengpaten untuk diolah lagi menjadi produk hanger baju. Bapak H. Noeh mempunyai peran penting karena beliau sebagai pemborong limbah dari pabrik itu, jadi para pengrajin membeli bahan baku atau materialnya dari beliau.

Circle hanger merupakan hanger yang berbentuk bulat yang awal munculnya pertama kali terbuat dari kayu yang diperkenalkan oleh Presiden Thomas Jefferen (Nurdiyansyah, 2012). Dalam proses pengembangan produk hanger yang kemudian diciptakan ulang oleh Albert J. Parkhouse yang terbuat dari besi dengan ide awal yaitu menggunakan sepotong kawat yang dibengkokkan menjadi lingkaran yang berlawanan arah kemudian melakukan putaran kawat ke ujung dan membentuknya menjadi pengait. Pada tahun 1904, kemudian dilakukan penjualan pertama kali oleh Meyer May pada tahun 1906 dengam merk Grand Rapids di kota Michigan yang dipromosikan dengan menggantungkan baju pada hangernya. Dalam perkembangan produk hanger yang sudah diproduksi dalam lingkup pabrikan sangat bermacam jenisnya dan dalam penyusun materialnya bermacam- macam, ada yang dari besi kawat dan ada yang dari kayu juga dari bahan plastik yang berbentuk unik. Perkembangan 
produk hanger ada juga yang berbentuk lingkaran yang diberi nama Circle hanger. Dalam produk circle hanger fungsinya sama dengan gantungan baju lainnya, keunggulananya yaitu pada bentuk yang unik dan muat digunakan untuk jemur banyak baju yang jenisnya untuk baju bayi, popok dll.

Berbicara tentang circle hanger untuk pemasarannya meliputi wilayah Kabupaten dan Kota Kediri bahkan sudah sampai dalam tahap pengiriman keluar kota, area Jawa Tengah. Pemiliki usaha circle hanger yaitu Bpk. Jono, yang sudah sekitar 13 tahun menjalankan usaha ini, dengan keunikannya yaitu penggunaan material yang berasal dari limbah besi. Para pekerja yang direkrut yaitu tetangga - tetangga sekitar yang ditampung kemudian diberikan pelatihan tentang pembuatan circle hanger dari limbah besi kawat yang dalam proses pendauran ulang yaitu dengan membersihkan besi kawat dari karat yang menempel, kemudian dilakukan pembentukan circle hanger . Dengan penggunaan tenaga kerja yang berasal dari masyarakat daerah Dusun Combong, akan berdampak pada hal mengurangi pengangguran dan menciptakan lapangan pekerja baik laki-laki maupun wanita, menambah penghasilan bagi yang mengikuti menjadi pekerja di pembuatan circle hanger. Pada pembuatannya lebih difokuskan kearah mensejahterakan, menambah motivasi, meningkatkan pengetahuan dunia teknologi dan cara menghasilkan produk circle hanger agar lebih dikenal dengan target penjualan yang sudah ditentukan. Dalam pembuatannya (Wibowo, Arifin, \& Sunarti, 2015), produk harus memiliki daya saing dipasaragar sesuai target penjualan terhadap produk tersebut. Para pekerja mempunyai bagian sendiri - sendiri mulai dari pengukuran, pemotongan, membengkokkan dan mengkrom serta mengkemas dengan plastik kemudian dikasih merk "Semar" dan siap dipasarkan. Dalam lingkup pemasarannya, mayoritas pengiriman ke daerah Babat, Lamongan, Tuban dan Jawa Tengah. Penitipan toko- toko yang sudah melakukan kerjasama dengan pemilik usaha ini juga dilakukan dalam artian disini titip barang nanti setiap bulannya bagian pemasaran mengecek barang yang terjual berapa banyak dan pihak took yang dititipi barang tersebut membayarnya.

Dalam permasalahan lingkungan yang sedang dihadapi oleh pemiliki usaha yaitu, bagaiman mengolah limbah agar tidak mencemari sungai dan area- area yang seharusnya bersih dari sampah. Maka, dalam langkah awal yaitu 10 tahun silam dahulu dimulai pengolahan limbah dan sampai saat ini, usaha holding hanger berkembang yang juga menerima pesanan dengan memberdayakan masyarakat sekitar agar menaikan profit penghasilan dan menambah kesejahteraan serta meningkatkan sumber daya manusia yang kreatif.

\section{METODE PELAKSANAAN}

Aktivitas yang digunakan untuk mengetahui tingkat kesejahteraan masyarakat dusun Combong dalam menjalankan industri kreatif produk circle hanger yaitu dengan metode kegiatan pengabdian masyarakat yang memberikan motivasi, inovasi dan edukasi melalui diskusi, ceramah, tanya jawab, simulasi yang dilaksanakan pada 14 Juli 2019 dengan topik Pemberdayaan Masyarakat melalui Pemanfaatan Limbah Besi dalam Pembuatan Produk Circle Hanger sebagai Peningkatan Kesejahteraan dan Industri Kreatif Berdaya Saing yang bertempat di Balai Pertemuan Dusun Combong, Desa Watengpaten, Kec. Gampengrejo, Kab. Kediri. Dalam kegiatan pengabdian masyarakat yang berlangsung sejak pukul 09.00-12.00 yaitu dalam tema tersebut dapat diambil kesimpulan bahwa dalam melaksanakan kegiatan industri kreatif tidak harus menggunakan bahan baku yang berasal dari pasar, tapi juga dapat dilakukan pembuatan produk dari bahan limbah agar dapat menambah nilai jual serta mengurangi efek negatif bagi lingkungan, dalam kegiatan tersebut yaitu pentingnya pemberdayaan masyarakat agar lebih mengenal dunia luar, mengenal cara perdagangan melalui antar kota, serta pemahaman 
tentang pentingnya kesejahteraan untuk masyarakat desa. Kegiatan tersebut akan memberi dampak positif, jika ada minat dan motivasi yang tinggi terhadap pelaku usaha beserta pekerjanya. Dengan durasi kurang lebih 3 jam, banyak sesi tanya jawab yang dilontarkan oleh masyarakat terhadap topik tersebut, dengan adanya sesi tanya jawab, masyarakat secara tidak langsung dapat menangkap maksud dari diadakannya pengabdian masyarakat ini.

\section{HASIL dan PEMBAHASAN}

Dengan adanya industri kreatif circle hanger di Dusun Combong, Desa Watengpaten, Kec. Gampengrejo, Kab. Kediri, masyarakat sekitar yang ingin belajar dan ingin melakukan usaha yang sama dapat dengan mudah mengaplikasikan keinginannya untuk menjadi pengusaha circle hanger. Capaian dari kegiatan ini yaitu mengarah bagaimana masyarakat bertindak untuk mensejahterakan individu maupun kelompoknya. Saat ini permintaan circle hanger dilihat dari segi penjualan banyak permintaan dari luar kota dan dilakukan penjualan ulang didaerah bersangkutan yaitu sebagai distributor. Capaian di dalam pengabdian masyarkat ini yaitu berupa capaian dari kegiatan - kegiatan pengabdian masyarakat yang telah dilakukan, dapat menghasilkan tujuan dan hasil yang sesuai dalam bentuk kesejahteraan masyarakat dalam hal ekonomi dan peningkatan inovasi pembuatan circle hanger yang memiliki nilai pasar dan berdaya saing.

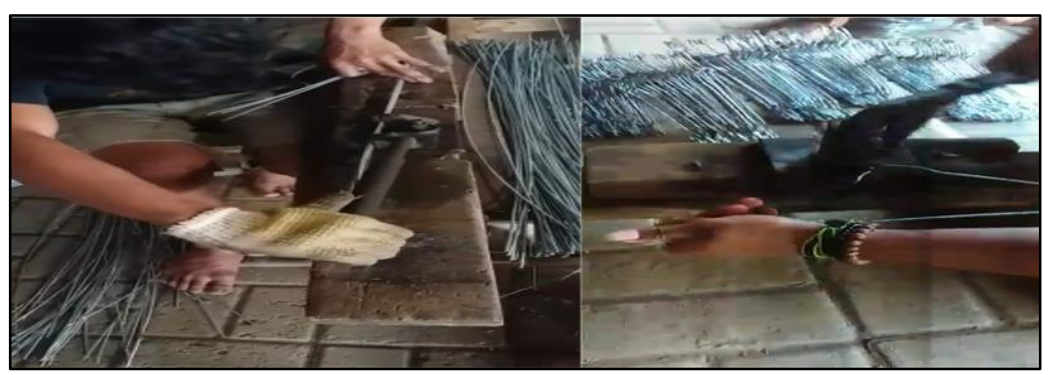

Gambar 1. Pembuatan Awal Circle Hanger (Sumber : Dari data para pekerja circle hanger)

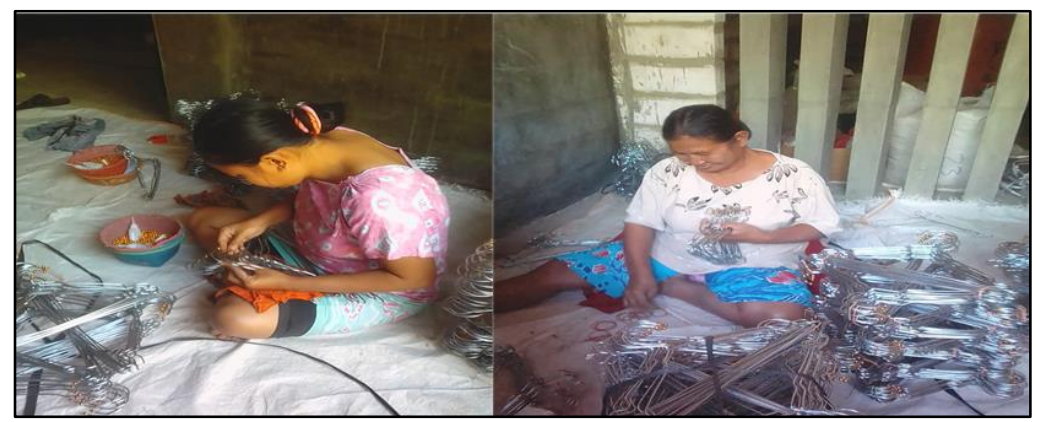

Gambar 2. Produk Awal Hanger biasa

(Sumber : Dari data para pekerja ibu rumah tangga warga setempat untuk masang manik manik) 


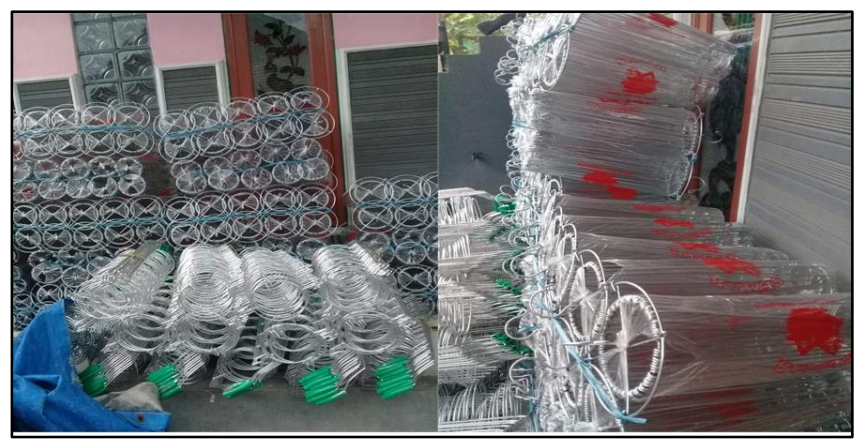

Gambar 3. Produk Jadi Circle Hanger

(Sumber : Data Produk jadi dari Circle Hanger)

\section{KESIMPULAN}

Kesimpulan dari kegiatan pengabdian masyarakat yaitu :

1. Alam pengembangan produk dari limbah akan mengurangi limbah di lingkungan dan mengurangi efek bahaya dari yang ditimbulkan.

2. Dari limbah menjadi berkah untuk warga dusun Combong.

3. Dengan adanya usaha pembuatan circle hanger dapat menambah ketrampilan masyarakat dan menambah pendapatan/hasil.

4. Circle hanger yang sudah diproduksi dapat tembus sampai daerah Jawa Tengah.

5. Penguatan dari segi aspek pemberdayaan masayarakat yaitu pemberian motivasi, dukungan dan edukasi, agar menimbulkan gerakan yang berdampak positif bagi lingkungan dan masayarakat sekitar dalam pembuatan inovasi dan pengembangan produk baru.

\section{DAFTAR PUSTAKA}

Miradj, S., \& Sumarno, S. (2017). Pemberdayaan Masyarakat Miskin, Melalui Proses Pendidikan Nonformal, Upaya Meningkatkan Kesejahteraan Sosial Di Kabupaten Halmahera Barat. Jurnal Pendidikan Dan Pemberdayaan Masyarakat, 1(1), 101. https://doi.org/10.21831/jppm.v1i1.2360

Nurdiyansyah, D. (2012). Albert J Parkhouse Sang Penemu. Retrieved July 18, 2019, from www.serupedia.com website: https://www.serupedia.com/2012/05/albert-jparkhouse-sang-penemu.html

Rohman, N. (2019). Industri Kreatif. Retrieved July 18, 2019, from akuntansionline.com website: https://akuntanonline.com/pengertian-industri-kreatif-menurut-para-ahlidan-contohnya/

Strategi Pengembangan Industri Kreatif.pdf. (n.d.).

Wibowo, D. H., Arifin, Z., \& Sunarti, . (2015). Analisis Strategi Pemasaran Untuk Meningkatkan Daya Saing UMKM (Studi pada Batik Diajeng Solo). Jurnal Administrasi Bisnis, 29(1), 59$66 . \quad$ Retrieved from http://administrasibisnis.studentjournal.ub.ac.id/index.php/jab/article/view/1172

Wulandari, A., Eripudia, \& Arifannisa. (2018). Sistem Pendidikan Indonesia dalam Peningkatan Mutu Pendidikan. Program Studi Matematika STKIP, 7(2), 9-16. 